\title{
A promoção da alfabetização científica nos anos finais do ensino fundamental por meio de uma sequência didática sobre crustáceos
}

\author{
Ellen Moreira da Costa*, Leonir Lorenzetti**
}

\section{Resumo}

O presente artigo tem como objetivo analisar as contribuições de uma sequência didática implementada em 2015, no $7^{\circ}$ ano do ensino fundamental de uma escola da rede pública no estado do Paraná. A sequência didática foi fundamentada por parâmetros da alfabetização científica e teve como temática os crustáceos. O estudo caracteriza-se como uma pesquisa de intervenção pedagógica. A constituição dos dados ocorreu mediante os diálogos que foram desenvolvidos durante as cinco aulas geminadas das disciplinas de Ciências e Atividades Experimentais. Como metodologia de análise utilizou-se a Análise Textual Discursiva. Para o planejamento da sequência didática foram empregadas as categorias de alfabetização científica conforme as divisões concebidas por Bybee (1995): funcional, processual e conceitual e multidimensional; conjuntamente, foram adotadas as categorias de Shen (1975), definidas por alfabetização científica prática, cívica e cultural. Essas categorias foram utilizadas nas análises como categorias a priori e, posteriormente, a elaboração de subcategorias mostrou-se importante para a análise. O resultados mostraram evidências das categorias de alfabetização científica de modo bastante claro, com exceção da alfabetização científica cultural, que não foi identificada. Algumas evidências da alfabetização científica emergiram do conhecimento prévio dos alunos e outras, pôde-se observar, foram promovidas por meio da sequência didática, que envolveu conhecimentos científicos, ambientais, sociais e econômicos em torno de sua temática. No decorrer da aplicação da sequência didática, notou-se que, progressivamente, os estudantes desenvolveram um posicionamento mais crítico em relação à importância científica, ambiental, social e econômica dos crustáceos, adquirindo conhecimentos e habilidades científicas em sintonia com os pressupostos da alfabetização científica.

Palavras-chave: Alfabetização Científica; Sequência Didática; Anos finais do Ensino Fundamental; Crustáceos.

\footnotetext{
* Mestre em Educação em Ciências em Matemática pela Universidade Federal do Paraná. Professora da Secretaria Estadual de Educação do Paraná, Brasil. E-mail: ellen.leeeh@gmail.com

* Doutor em Educação Científica e Tecnológica pela Universidade Federal de Santa Catarina. Professor do Departamento de Química e do Programa de Pós-Graduação em Educação em Ciências e em Matemática da Universidade Federal do Paraná, Brasil. E-mail: leonirlorenzetti22@gmail.com
}

Recebido em: 29/09/2019 - Aceito em: 30/10/2019.

https://doi.org/10.5335/rbecm.v3i1.10006

http://creativecommons.org/licenses/by-nc-nd/4.0 


\section{Introdução}

Diante do atual cenário social e econômico, é preciso que o corpo docente esteja engajado na discussão sobre a formação de cidadãos conscientes, buscando promover uma educação reflexiva e sujeitos atuantes na tomada de decisões. Segundo Strieder (2008; 2012), desde os anos 80 do século passado busca-se planejar o ensino de acordo com a realidade brasileira, ganhando relevo nessa época as reflexões sobre a necessidade de construir modelos educacionais que abordassem a tríade ciência, tecnologia e sociedade. Assim, cabe ao ensino das ciências abordar desde os primeiros anos essas dimensões de uma maneira que estimule os estudantes a relacionar os fenômenos naturais com a vida dentro de quadro humanístico de compreensão de mundo.

Esses pressupostos estão em sintonia com a Alfabetização Científica (AC), a qual é conceituada por Lorenzetti (2000, p. 11) como "[...] o processo pelo qual a linguagem das Ciências Naturais adquire significados, constituindo-se num meio para o indivíduo ampliar o seu universo de conhecimentos, a sua cultura como cidadão inserido na sociedade”. Diante da importância dessa concepção, Stuart e Marcondes (2017) defendem que ela deve ser um norte para o ensino em todos os anos escolares. Salientam ainda a importância de mudanças e reformas educativas, as quais devem apresentar a finalidade de desenvolver habilidades e competências aos estudantes.

Em análise de trabalhos apresentados no Enpec, Costa e Lorenzetti (2018) identificaram que ainda são incipientes as pesquisas que abordam a alfabetização científica nos anos finais do ensino fundamental, apesar da importância desta fase para o desenvolvimento do estudante. O presente estudo pretende nutrir este campo específico da pesquisa docente em ciências. Seu objetivo foi a análise das contribuições de uma sequência didática fundada pelos princípios da alfabetização científica.

$\mathrm{O}$ artigo discorre sobre a proposta, aplicação e análise de uma sequência didática elaborada com vistas a aproximar o conhecimento científico da realidade dos estudantes. O planejamento vai ao encontro da concepção de Auler e Delizoicov (2001), que salientam a necessidade de repensar a formação escolar com intuito de preparar o indivíduo para tomar decisões, agir e compreender as implicações da ciência no mundo. Baseada na temática crustáceos, a sequência didática foi produzida visando a alfabetização científica de uma turma do $7^{\circ}$ ano do ensino fundamental de uma 
escola de ensino integral. A partir do tema principal, são abordados os temas a ele relacionados, tocantes à perspectiva ambiental, econômica e social, bem como sua influência no cotidiano dos estudantes.

\section{A Alfabetização Científica e suas categorias}

É inegável a presença da Ciência e da Tecnologia na sociedade, sendo a escola, por meio do ensino de ciências, um espaço profícuo para análise das implicações do conhecimento científico na vida pessoal e profissional dos alunos e de seus familiares. Nesse sentido, muito se discute sobre a necessidade da educação em ciências incorporar os pressupostos da alfabetização científica, mirando uma formação científica que promova a cidadania. Como afirma Driver et al. (1999), os objetivos do ensino de ciências não podem se restringir a compreender conceitos e fenômenos da natureza.

Chassot (2003) salienta a necessidade de ofertar o ensino de maneira mais relevante e crítica na escola, contribuindo com a formação de um ambiente de aprendizagem que incentive debates e discussões sobre questões relacionadas à ciência. Entretanto, é necessário trabalhar os conceitos científicos de modo participativo e contextualizado, para que, ao se depararem com problemas complexos, os estudantes possam utilizar seu conhecimento de maneira crítica para construir julgamentos, posicionando-se frente a assuntos relacionados à ciência e à tecnologia que permeiam a sociedade.

Assim, ao desenvolver as ciências nos anos finais do ensino fundamental, consideramos a necessidade de conexão das aulas com o mundo concreto, por meio da interdisciplinaridade, relacionando os conceitos científicos a contextos reais. Tem-se também a finalidade de compreender a natureza histórica da ciência, de modo a alcançar uma perspectiva mais ampla e promover a alfabetização científica (ARAÚJO, 2014).

O desenvolvimento da $\mathrm{AC}$ envolve a compreensão dos conceitos científicos e sua articulação a contextos. $\mathrm{O}$ aluno deve ser capaz tanto de refletir sobre a ciência e suas mudanças, quanto a reconhecer as variadas aplicações da ciência na vida prática. Com isso, os estudantes podem se preparar para a participação no processo democrático da sociedade, o que Iglesia (1995) acredita ser o caminho para a formação cidadã, sendo fundamental para a promoção da AC.

Teixeira (2013, p. 796) defende a ideia de que: 
[...] pensar sobre os significados de AC é pensar sobre as funções da educação científica, qual o seu papel, onde ela acontece e de quais formas; é em última instância pensar sobre o que é educação científica, o que se pretende com tal educação, de que forma podemos alcançá-la e quais os modos pelos quais podemos avaliar se de fato os objetivos almejados foram alcançados.

A partir disso, almejamos que o ensino de ciências possibilite a compreensão de que os estudantes podem transformar a realidade em que vivem com consciência e conhecimento, de maneira crítica. Ou seja, a $\mathrm{AC}$ visa formar cidadãos que não aceitem imposições tocantes a aspectos científicos sem antes questioná-los e compreendê-los.

Isso é o objetivo da Alfabetização Científica, capacitar os estudantes a compreenderem os fenômenos científicos, suas relações ecológicas, sociais e ambientais, de forma a tornarem-se mais ativos e críticos diante de situações relacionadas à ciência e tecnologia. Assim, poderão estar preparados para compreender o mundo natural, relacionando experiências do cotidiano, podendo nelas intervir com competência, por meio do envolvimento e interpretação do conhecimento científico. Logo, a AC pode ser compreendida como a capacidade de ler, compreender e expressar opinião sobre assuntos relacionados à ciência (MILLER, 1983). Inclui o exercício de reflexão sobre a ciência, o incentivo a autonomia intelectual do estudante e contribui para sua formação crítica.

O termo alfabetização científica, provém de scientific literacy, termo inglês muito utilizada nos anos 60 do século passado, tendo sido introduzida em 1958 por Paul Hurd. Segundo Laugksch (2000), essa década foi precursora da expressão, que ainda não tinha uma definição. Décadas depois começaram a surgir novas interpretações para o termo, o qual foi progressivamente se difundindo pelo mundo.

Ao se promover a AC no contexto escolar e nos espaços não formais, almeja-se que os indivíduos sejam capazes de ampliar seus conhecimentos científicos - o que pode acontecer em qualquer fase da vida, uma vez que a alfabetização científica é uma atividade vitalícia e um processo permanente (LORENZETTI, 2000).

Nos anos finais do ensino fundamental os estudantes já apresentam uma maior compreensão da ciência e da tecnologia e das suas implicações sociais. Isso será proporcionado na escola, na medida em que os alunos vivenciam situações de aprendizagem que contribuem para a construção de conhecimentos científicos. Para que se chegue a isso, cabe ao docente o papel fundamental de adequar e adaptar o 
ensino de acordo com a realidade do estudante, contextualizando, problematizando e apresentando situações de aprendizagem, visando alcançar as metas do ensino de ciências. Para Cachapuz et al. (2005) o professor deve ser capaz de ajudar os estudantes a desenvolverem perspectivas da ciência e tecnologia. Nesse sentido, consideramos que a promoção da alfabetização científica é uma das metas da educação em ciências na contemporaneidade.

Diante disso, apontamos que este trabalho vai ao encontro dos pressupostos da AC, uma vez que, de acordo com Milaré, Richetti e Pinho Alves (2009), um dos pressupostos da AC é - relacionar as práticas educativas do ensino de ciências de uma maneira que permita o aprimoramento da leitura crítica do mundo, contribuindo para a formação cidadã, pautado em uma metodologia diversificada, abarcando uma variedade de recursos didáticos que envolvem tanto o espaço formal como o não formal.

Neste artigo utilizaremos as categorias de alfabetização científica propostas por Shen (1975) e Bybee (1995) para analisar se a sequência didática sobre crustáceos, desenvolvida com alunos dos anos finais do Ensino Fundamental, promove a alfabetização científica.

Esses autores apresentam um conjunto de categorias que possibilitam avaliar as dimensões da alfabetização científica e estas têm, com isso, sido amplamente adotadas nas pesquisas em educação em ciências. As categorias de alfabetização científica prática, cívica e cultural de Shen têm sido utilizadas nas pesquisas de Milaré, Richetti e Alves Filho (2009), Stanzani, Broietti e Souza (2016), Lorenzetti, Siemsen e Oliveira (2017), Domicino, Lorenzetti, Reis e Joucoski (2017), Costa e Lorenzetti (2017; 2018), Pflanzer (2017), Siemsen (2019). As categorias de alfabetização científica funcional, conceitual e processual e multidimensional de Bybee (1995) foram utilizadas por Rosa, Lambach e Lorenzetti (2017), Rosa (2018).

Shen (1975) difere suas categorias em relação aos objetivos, pelos seguintes critérios: público a que se dirige, formato e meios de disseminação. As categorias propostas destacam as intencionalidades da ação docente, indicando as metas da educação em ciências.

Segundo Shen (1975, p. 265, tradução nossa), a Alfabetização Científica Prática determina a "posse do tipo de conhecimento científico que pode ser usado para ajudar a resolver problemas práticos”. Esta alfabetização deve proporcionar "um tipo de conhecimento científico e técnico que pode ser posto em uso imediata- 
mente, para ajudar a melhorar os padrões de vida" (SHEN, 1975, p. 265, tradução nossa). Está intimamente ligada aos conhecimentos básicos e imediatos que atendem às necessidades humanas para a sobrevivência, relacionadas à alimentação, saúde, higiene e abrigo. Diante disso, pode-se considerar que são conhecimentos que representam processos básicos utilizados no dia a dia das pessoas com intuito de melhorar as condições cotidianas. Entende-se que a AC prática pode ser facilmente desenvolvida, abarcando elementos fundamentais da atualidade, sejam quais forem: a contextualização, a compreensão do conhecimento científico e a aplicação deste conhecimento, além da aproximação do mundo vivido com o mundo da escola. Portanto, compreende-se que a incorporação destes elementos no ensino de ciências traz elementos didáticos e concretos para a formação do cidadão.

A Alfabetização Científica Cívica é aquela que torna o cidadão mais atento à ciência e a seus problemas, de modo que ele possa tomar decisões de modo mais bem informado. Assim, o cidadão é capacitado a "tornar-se mais informado sobre a ciência e as questões relacionados a ela, tanto que ele e seus representantes podem trazer seu senso comum para apreciá-lo e, desta forma, participar mais intensamente no processo democrático de uma sociedade crescentemente tecnológica" (SHEN, 1975, p. 266, tradução nossa). Segundo o autor, para que a AC cívica seja promovida é necessário que os indivíduos sejam mais expostos à ciência e que possam analisar a complexidade dos assuntos que envolvem a ciência, utilizando uma linguagem clara que permita a compreensão das explicações científicas.

Já a Alfabetização Científica Cultural "é motivada por um desejo de saber algo sobre ciência, como uma realização humana fundamental; ela é para a ciência, o que a apreciação da música é para o músico. Ela não resolve nenhum problema prático diretamente, mas ajuda a abrir caminhos para a ampliação entre as culturas científicas e humanísticas" (SHEN, 1975, p. 267; tradução nossa). Contribui para a ampliação do conhecimento dos indivíduos, podendo desenvolver autonomia intelectual, estimulando os estudantes a aprender mais sobre um determinado assunto, a pesquisar e a relacioná-los a outros contextos por iniciativa própria.

Pautado nos pressupostos da AC, mas com uma visão voltada para a aquisição de conhecimentos científicos, Bybee (1995) apresenta três dimensões da alfabetização científica, denominadas de alfabetização científica "funcional", "conceitual e processual" e "multidimensional". 
A Alfabetização Científica Funcional objetiva o desenvolvimento de conceitos, centrando-se na aquisição de um vocabulário, termos técnicos que envolvem ciência e tecnologia. Neste domínio da alfabetização científica, os alunos percebem que a ciência utiliza vocábulos próprios. Assim, "de acordo com a idade dos educandos, fase de desenvolvimento, e o nível de educação, os estudantes deveriam estar aptos a ler e escrever passagens que incluem vocabulário científico e tecnológico" (BYBEE, 1995, p. 29, tradução nossa).

Na Alfabetização Científica Conceitual e Processual, os alunos já atribuem significados próprios aos conceitos científicos, relacionando-os a informações e fatos sobre ciência e tecnologia. Observa-se que o ensino não se resume a vocabulário, informações e fatos sobre ciência e tecnologia. Inclui habilidades e compreensões relativas a procedimentos e processos que fazem da ciência um dos caminhos para o conhecimento, ou seja, não se dicotomiza os processos e os produtos da ciência.

Já no nível da Alfabetização Científica Multidimensional, os alunos são capazes de adquirir e explicar conhecimentos, além de aplicá-los à solução de problemas do dia a dia. Assim, para além do vocabulário, essa categoria estende-se a esquemas conceituais e métodos processuais, incluindo compreensões sobre ciência. "Nós temos de ajudar os estudantes a desenvolver perspectivas de ciência e tecnologia que incluam a história das ideias científicas, a natureza da ciência e da tecnologia, e o papel da ciência e da tecnologia na vida pessoal e na sociedade" (YAGER 1990, apud BYBEE, 1995, p. 29, tradução nossa).

Importante destacar que na literatura encontramos, além das categorias de Shen e de Bybee, os indicadores de alfabetização científica de Sasseron e Carvalho (2008) e de Pizarro e Lopes Junior (2015). Porém, neste trabalho as categorias de AC de Shen e Bybee foram consideradas mais adequadas, e por isso foram utilizadas no planejamento e na análise da sequência didática.

\section{Metodologia}

O estudo consiste em uma pesquisa exploratória, de cunho qualitativo e de tipo intervenção pedagógica (DAMIANI et al., 2013). A sequência didática foi estruturada com base nos Três Momentos Pedagógicos (3MP): problematização inicial, organização do conteúdo e aplicação do conteúdo (DELIZOICOV; ANGOTTI; PERNAMBUCO, 2011). Os momentos são orientados pelos pressupostos da Alfabetização Científica, 
e englobam as questões científicas, ambientais, econômicas e sociais que envolvem a temática crustáceos.

A escolha da temática crustáceo se deve ao fato de compor o conteúdo programático do $7^{\circ}$ ano nas Diretrizes Curriculares do Estado do Paraná, bem como a existência de um trabalho iniciado na escola em anos anteriores. Esse trabalho envolve um projeto de visita técnica ao museu e aquário da cidade de Paranaguá-PR, abordando temáticas relacionadas ao ambiente marinho. Porém, em função de questões financeiras, não foi possível realizar a visita no ano de implementação da sequência didática.

A sequência didática foi implementada numa turma composta de 17 alunos que frequentavam o $7^{\circ}$ ano do ensino fundamental no ano de 2015, em uma escola de período integral da rede pública estadual do Paraná situada no município de Curitiba.

A escola em que a pesquisa foi desenvolvida oferta o ensino em tempo integral de turno único, disponibilizando disciplinas regulares, contempladas na Base Nacional Comum Curricular, e as diversificadas, que são selecionadas pela equipe pedagógica e pelos professores da instituição, sendo vinculadas às regulares e, com a ementa aprovada pela Secretaria de Educação do Estado do Paraná, são ofertadas nos turnos da manhã e tarde. A escolha da instituição se deu por ser a escola em que um dos autores leciona, além de sua localização ser próxima ao litoral paranaense, onde há uma vasta área de manguezais que comportam algumas espécies de crustáceos. Diante disso, a temática mostra-se relevante, uma vez que busca integrar o conhecimento científico com a realidade que cerca os estudantes, ao incorporar questões científicas, ambientais, sociais e econômicas, sendo um conteúdo que faz parte das Diretrizes Curriculares Estaduais do Paraná.

A sequência didática proposta foi desenvolvida de acordo com as características das disciplinas de Ciências (disciplina regular) e Atividades Experimentais (disciplina diversificada), sendo implementada em 5 aulas geminadas, com a duração de 100 minutos cada. No Quadro 1 apresentamos a estruturação da sequência didática que foi denominada "Credo! ... O que é aquele bicho que anda tão rápido na lama?" 
Quadro 1: Estrutura da Sequência didática

(continua...)

\begin{tabular}{|c|c|c|}
\hline Objetivos & Conteúdos Científico & Recursos Didáticos \\
\hline \multicolumn{3}{|c|}{ Aula 01} \\
\hline $\begin{array}{l}\text { Estabelecer tipos de relação bio- } \\
\text { lógica do caranguejo com outras } \\
\text { espécies e diferentes ambientes. } \\
\text { Investigar quais as relações do ca- } \\
\text { ranguejo com o ser humano. } \\
\text { Identificar espécies brasileiras de } \\
\text { caranguejos e suas diferenças ta- } \\
\text { xonômicas. }\end{array}$ & $\begin{array}{l}\text { Relações Biológicas. Con- } \\
\text { ceito de espécie. Nomen- } \\
\text { clatura científica. Taxono- } \\
\text { mia. }\end{array}$ & $\begin{array}{l}\text { Música de Gordurinha "Vende- } \\
\text { dor de caranguejos" cantada } \\
\text { por Gilberto Gil. } \\
\text { Imagens de espécies brasilei- } \\
\text { ras de caranguejo. Laboratório } \\
\text { de informática: computadores. } \\
\text { Reportagem Gazeta do povo } \\
\text { online - "Captura do Caran- } \\
\text { guejo-Uçá está liberada no } \\
\text { Paraná, com restrições." }\end{array}$ \\
\hline \multicolumn{3}{|c|}{ Aula 02} \\
\hline $\begin{array}{l}\text { Compreender o que é um habitat } \\
\text { e as condições necessárias para } \\
\text { se formar o ambiente adequado ao } \\
\text { caranguejo. } \\
\text { Conhecer e identificar o habitat do } \\
\text { caranguejo. } \\
\text { Investigar o hábito de vida de um } \\
\text { caranguejo. } \\
\text { Identificar as condições ideais para } \\
\text { sobrevivência do caranguejo. } \\
\text { Conhecer e identificar as caracte- } \\
\text { rísticas do manguezal. } \\
\text { Conhecer outras espécies que ha- } \\
\text { bitam o mangue. }\end{array}$ & $\begin{array}{l}\text { Hábito de vida do carangue- } \\
\text { jo. } \\
\text { Habitat e Nicho do caran- } \\
\text { guejo. } \\
\text { Adaptação para a sobrevi- } \\
\text { vência dos caranguejos em } \\
\text { diferentes ambientes. }\end{array}$ & $\begin{array}{l}\text { Vídeos. Cantiga de roda "Ca- } \\
\text { ranguejo peixe é". Texto cien- } \\
\text { tífico - Ciência Hoje "A vida no } \\
\text { mangue". Reportagem sobre o } \\
\text { Projeto Uçá. }\end{array}$ \\
\hline \multicolumn{3}{|c|}{ Aula 03} \\
\hline $\begin{array}{l}\text { Investigar o manejo do caranguejo } \\
\text { pelo ser humano. } \\
\text { Identificar a importância econômi- } \\
\text { ca do caranguejo. } \\
\text { Analisar os períodos de captura e } \\
\text { venda do caranguejo. } \\
\text { Analisar a rotina da profissão do } \\
\text { catador/ vendedor de caranguejos. } \\
\text { Elencar as vantagens e desvanta- } \\
\text { gens da profissão. } \\
\text { Analisar a influência do caranguejo } \\
\text { para a culinária. }\end{array}$ & $\begin{array}{l}\text { Relevância da criação do } \\
\text { caranguejo. Impactos am- } \\
\text { bientais causados através } \\
\text { do processo de captura do } \\
\text { caranguejo. Consequências } \\
\text { da presença humana para } \\
\text { o bem-estar do caranguejo } \\
\text { e outras espécies que habi- } \\
\text { tam o mangue. Organização } \\
\text { sociocultural e ambiental do } \\
\text { cotidiano dos catadores. } \\
\text { Cotidiano dos catadores/ } \\
\text { vendedores de caranguejo. }\end{array}$ & $\begin{array}{l}\text { Vídeos. Texto científico - Re- } \\
\text { vista Ciência Hoje - "Jardinei- } \\
\text { ro do manguezal". }\end{array}$ \\
\hline
\end{tabular}




\begin{tabular}{|c|c|c|}
\hline \multicolumn{3}{|c|}{ Aula 04} \\
\hline $\begin{array}{l}\text { Identificar a importância ambiental } \\
\text { do caranguejo. } \\
\text { Conhecer e refletir sobre os riscos } \\
\text { de extinção de espécies brasileiras } \\
\text { de caranguejo. } \\
\text { Analisar as principais causas de } \\
\text { extinção dos caranguejos no Brasil. } \\
\text { Identificar a época e condição ide- } \\
\text { al para a realização da captura dos } \\
\text { caranguejos em algumas regiões. } \\
\text { Analisar a necessidade da captura } \\
\text { dos caranguejos. } \\
\text { Conhecer a lei que discute o tempo } \\
\text { legal para a catação do caranguejo } \\
\text { em algumas regiões brasileiras. } \\
\text { Discutir medidas para amenizar os } \\
\text { impactos gerados aos caranguejos. }\end{array}$ & $\begin{array}{l}\text { Preservação do ecossiste- } \\
\text { ma. Extinção de espécies. } \\
\text { Importância econômica e } \\
\text { ambiental do manguezal. } \\
\text { Importância dos seres vi- } \\
\text { vos para os ecossistemas- } \\
\text { mangue. }\end{array}$ & $\begin{array}{l}\text { Vídeos. Imagens. } \\
\text { Lei federal do IBAMA. } \\
\text { Revista "Menino Caranguejo". }\end{array}$ \\
\hline \multicolumn{3}{|c|}{ Aula 05} \\
\hline $\begin{array}{l}\text { Identificar características dos crus- } \\
\text { táceos. } \\
\text { Identificar os animais que fazem } \\
\text { parte dos crustáceos. } \\
\text { Compreender e diferenciar as ca- } \\
\text { racterísticas taxonômicas de cada } \\
\text { espécie de crustáceo. } \\
\text { Reconhecer e identificar as carac- } \\
\text { terísticas como adaptações para o } \\
\text { hábito de vida de um animal. } \\
\text { Analisar as características dos } \\
\text { exemplares de crustáceos com os } \\
\text { artrópodes. } \\
\text { Relacionar semelhanças e diferen- } \\
\text { ças entre os crustáceos, perten- } \\
\text { centes ao filo dos artrópodes. }\end{array}$ & $\begin{array}{l}\text { Características dos Crustá- } \\
\text { ceos. Diferenças morfoló- } \\
\text { gicas entre os crustáceos. } \\
\text { Diferenças e semelhanças } \\
\text { morfológicas entre os artró- } \\
\text { podes. }\end{array}$ & $\begin{array}{l}\text { Vídeo. Poesia. Exemplares de } \\
\text { crustáceos do Museu de His- } \\
\text { tória Natural da Universidade } \\
\text { Federal do Paraná (UFPR). }\end{array}$ \\
\hline
\end{tabular}

Fonte: Os autores (2019).

$\mathrm{Na}$ aula 1 a problematização inicial ocorreu com a música "Vendedor de caranguejos", sendo que o professor apresentou os seguintes questionamentos: 1) na sua concepção o que está sendo abordado na música? 2) quais são os seres vivos citados na música? 3) na canção aparece o nome desses seres vivos, como vocês identificaram? 4) existe alguma relação entre o caranguejo e o ser humano? 5) quais seriam essas relações? Em seguida, na organização do conhecimento, o professor solicitou que os 
alunos destacassem, com cores diferentes, trechos que correspondessem às etapas de captura e venda do caranguejo, às espécies de caranguejo citadas na música e os trechos associados à vida cotidiana do vendedor de caranguejos. Em seguida, receberam cartas com imagens de diferentes espécies brasileiras de caranguejos, para auxiliar na discussão do significado do termo "espécie". Cada carta, tinha um quadro a ser preenchido com as principais características desses caranguejos, com intuito de identificar a diferença entre as espécies, sendo utilizado o laboratório de informática para a pesquisa. Ao término da atividade os alunos jogaram o Super Trunfo $^{1}$ montado por eles. Na etapa de aplicação do conhecimento, os estudantes receberam uma reportagem sobre o processo de captura dos caranguejos no estado do Paraná. O objetivo foi aproximar o fato de sua realidade, reconhecendo a procedência dos caranguejos no estado do Paraná. Por meio das imagens das cartas, os alunos identificaram quais as espécies podem ser encontradas nas regiões litorâneas próximas à moradia dos alunos. Também discutiram sobre a importância da época para captura do caranguejo.

$\mathrm{Na}$ aula 2 os estudantes cantaram a canção "Caranguejo não é peixe”. Em seguida, discutiram e problematizaram a afirmação que dá nome a música, relacionando aspectos sobre a vida dos animais citados na cantiga de roda. As seguintes questões envolveram a problematização inicial: 1) onde vocês acham que podem viver os caranguejos? 2) como vocês pensam que é viver nesses locais para o caranguejo? 3) quais as possíveis consequências de viver nesse local? 4) como vocês acham que deve ser um lugar apropriado para os caranguejos viverem melhor? 5) vocês acham que os caranguejos vivem sozinhos, isolados? 6) quais os outros seres vivos que vocês acham que poderiam viver no mesmo lugar que os caranguejos? $\mathrm{Na}$ etapa de organização do conhecimento os estudantes assistiram dois vídeos. O primeiro demonstrou as características do manguezal, expondo as condições ideais para sua ocorrência, para a vida das espécies que lá habitam e o segundo vídeo mostrou o hábito de vida dos caranguejos. Em seguida, discutiram as características do manguezal e das espécies locais. Posteriormente, receberam um texto científico que apresenta características particulares dos caranguejos. Depois de ler o texto, relacionaram o que viram nos vídeos com os subtítulos do texto, que descreviam características adaptativas para sobrevivência no manguezal. Na fase de aplicação do conhecimento os estudantes leram um texto científico que aborda relações diretas 
do caranguejo uçá no manguezal, levando-os a questionar-se sobre a utilização do caranguejo pelo ser humano e a adaptação ao mangue.

$\mathrm{Na}$ aula 3 foi exibido o trecho de uma reportagem televisionada, sem áudio, mostrando a vida de um catador/vendedor de caranguejos, levando os estudantes a questionarem como é a vida dessas pessoas. As seguintes questões foram propostas na problematização inicial: 1) vocês acham que um ser humano é capaz de sobreviver no manguezal? 2) como um ser humano pode viver e sobreviver no manguezal? 3) como seria o abrigo e a locomoção dos seres humanos nesses locais? 4) se vocês precisassem capturar caranguejo, como fariam? 5) como vocês imaginam que é a rotina das pessoas que tem essa profissão? 6) quais as consequências de vida dessas pessoas? Na organização do conhecimento foi entregue a letra da música "vendedor de caranguejos", trabalhada na primeira aula, para estimular os estudantes a levantarem os motivos que fazem as pessoas irem até o manguezal, questionando-se como seria frequentar esse local diariamente. Em seguida, os estudantes assistiram dois vídeos que demonstram o processo de captura do caranguejo, desde o preparo do catador até o momento da venda. O propósito dos vídeos foi promover reflexão e discutir o cotidiano do vendedor de caranguejos. Um dos vídeos foi gravado em Pontal do Paraná, cidade litorânea do estado do Paraná, a qual todos os estudantes alegaram que conheciam, o que facilitou a aproximação do ensino com a sua realidade. Na aplicação do conhecimento os estudantes receberam um texto científico que compara o Caranguejo Uçá com um jardineiro, neste caso, do manguezal. A leitura desse texto, teve a finalidade de apresentar a importância ambiental dos caranguejos na natureza, em específico no seu habitat, o mangue. Com isso, o estudante foi suscitado a refletir sobre a forte influência do caranguejo para a culinária, relacionando os danos causados pela coleta de fêmeas, assim como pela captura durante o período de defeso do animal, a desova e o crescimento de novos crustáceos. Esse momento buscou estimular a reflexão do uso sustentável do manguezal, descrevendo como seria um consumidor consciente, compreendendo a importância de se preservar espécies e os ecossistemas, levando os estudantes a se posicionarem sobre o assunto.

A Aula 4 teve início com imagens de manguezais poluídos e outros em boas condições. Como problematização inicial foram propostas as seguintes questões: 1) quais dessas imagens apresenta um habitat em boas condições? Por quê? 2) quais as consequências de um ambiente poluído? 3) por qual motivo vocês acham que os 
caranguejos são capturados dos mangues? Quais seriam as utilizações do caranguejo pelo ser humano? 4) vocês já tiveram algum contato com essa espécie? Vivo ou morto? 5) quais as necessidades de se viver em um local adequado? 6) quais seriam as vantagens de viver em lugares limpos? $\mathrm{E}$ as desvantagens de viver um lugar poluído, sujo? 7) vocês já se alimentaram de caranguejo? Na organização do conhecimento os alunos assistiram uma reportagem que aborda a importância econômica das espécies de caranguejos, utilizada na culinária. Em consequência da grande valorização dessa espécie, o Instituto Brasileiro do Meio Ambiente e Recursos Naturais (IBAMA), instituiu uma lei que atende às necessidades para a sobrevivência dessa espécie, estipulando a maneira ideal para a captura e conservação dos caranguejos. Os estudantes tiveram contato com essa lei para tomarem conhecimento de que os caranguejos têm amparo legal contra a extinção, compreendendo o motivo das formulações das leis. Posteriormente, foi apresentado que o caranguejo-uçá, espécie de caranguejo mais numerosa do país, está correndo sério risco de extinção no Brasil, levando os estudantes a se questionarem sobre os motivos que podem causar a extinção da espécie. Na etapa de aplicação do conhecimento os estudantes leram uma história em quadrinhos, a qual tem como seu personagem principal, um caranguejo. Essa produção da UNIVILLE tem o objetivo de proporcionar e auxiliar a educação ambiental nas escolas, mostrando a realidade dos biomas para os estudantes. A história expõe não só a degradação dos manguezais, mas as consequências geradas ao meio ambiente devido à interferência do ser humano. Com isso, os estudantes discutiram medidas para amenizar o dano e preservar esses ambientes.

A aula 5 foi desenvolvida no laboratório de Ciências. Ao entrarem no laboratório, os estudantes se depararam com diferentes espécies de crustáceos conservadas no álcool e no formol. As espécies foram distribuídas nas bancadas para análise e identificação dos animais por meio de suas características, respondendo as seguintes questões da problematização inicial: 1) vocês sabem quais são esses animais? 2) vocês já viram esses animais? 3) onde vocês acham que podemos localizar esses animais? É mais fácil localizá-los vivos ou mortos? Na etapa da organização do conhecimento os alunos receberam um poema de Manoel de Barros intitulado "Se achante", que atribui aspectos humanos e sociais ao comportamento e à morfologia do caranguejo, cumprindo a finalidade do instigar comparações. Posteriormente, os estudantes observaram os exemplares taxidermizados e organizaram uma tabela com as características de cada uma das espécies de crustáceos, analisando sua 
morfologia e suas possíveis atitudes comportamentais, de acordo com o hábito de vida desses animais. Na etapa de aplicação do conhecimento os estudantes escutaram um trecho de uma música, que chama atenção para a principal característica do caranguejo - caranguejo é quem anda para trás - com intuito de estimular o estudante a pensar sobre o fato. Ao discutir sobre tal, levantaram hipóteses do motivo de o caranguejo não se locomover como outros animais, ou mesmo como outros crustáceos ou artrópodes, sendo que todos fazem parte da mesma classificação. Dessa maneira, os estudantes relacionaram as características dos crustáceos e do caranguejo, com as características do filo a que pertencem - os artrópodes -, ressaltando que todas as características fazem parte de um processo de adaptação ao ambiente em que vivem.

Para a constituição dos dados para a análise foram consideradas as gravações dos diálogos estabelecidos entre os alunos e a professora/pesquisadora durante as atividades realizadas pelos alunos durante as aulas e os relatórios finais. Este corpus foi analisado de acordo com a metodologia da Análise Textual Discursiva (ATD) de Moraes e Galiazzi (2007), que consiste na unitarização, categorização e comunicação.

Inicialmente os dados foram analisados identificando as unidades de contexto e a sua posterior categorização. Moraes e Galiazzi (2007, p. 75) ressaltam que a construção das categorias de análise ocorre pelo agrupamento de unidades, ou seja, "um conjunto desorganizado de elementos unitários é ordenado no sentido de expressar novas compreensões atingidas no decorrer do processo". Esse processo pode surgir partir de dois aspectos, de natureza objetiva e dedutiva, estabelecendo as categorias a priori, e outro indutivo e subjetivo, determinando as categorias emergentes.

No âmbito desta pesquisa, a elaboração das categorias definidas a priori partiu de referenciais teóricos utilizados para fundamentação e construção da sequência didática, bem como para o desenvolvimento das aulas. Assim, constituíram-se como categorias a priori: Alfabetização Científica Prática, Alfabetização Científica Cívica e Alfabetização Científica Cultural, propostas por Shen (1975) e as categorias de Bybee (1995) Alfabetização Científica Funcional, Alfabetização Científica Processual e Conceitual e Alfabetização Científica Multidimensional.

Com isso, buscamos vincular os pressupostos dos parâmetros de AC a novos olhares referentes às categorias, associadas ao recorte dos dados da pesquisa. Após a análise e interpretação dos dados surgiram novos elementos significativos, que 
acrescentaram pontos ao significado das categorias a priori, o que exigiu a elaboração de subcategorias, conforme apresentadas no Quadro 2.

Quadro 2: Categorias e subcategrias de análise

\begin{tabular}{|l|l|}
\hline \multirow{2}{*}{ Categorias a priori } & \multicolumn{1}{c|}{ Subcategorias } \\
\hline \multirow{2}{*}{$\begin{array}{l}\text { AC conceitual e } \\
\text { processual }\end{array}$} & Identificar e utilizar termos científicos assimilados anteriormente. \\
\cline { 2 - 2 } & Utilizar novos termos científicos adquiridos. \\
\cline { 2 - 2 } $\begin{array}{l}\text { AC multidimen- } \\
\text { sional }\end{array}$ & Definir novos conceitos científicos adquiridos. \\
\hline \multirow{3}{*}{ AC prática } & Relacionar e aplicar os conteúdos estudados anteriormente. \\
\cline { 2 - 2 } & $\begin{array}{l}\text { Relacionar os conhecimentos apreendidos anteriormente para resolução de } \\
\text { problemas científicos. }\end{array}$ \\
\cline { 2 - 2 } & $\begin{array}{l}\text { Apreender os novos conhecimentos estudados, como resolução de proble- } \\
\text { mas científicos. }\end{array}$ \\
\hline \multirow{2}{*}{ AC cívica } & $\begin{array}{l}\text { Posicionamento sobre questões relacionadas à sociedade com base em } \\
\text { conhecimentos prévios. }\end{array}$ \\
\cline { 2 - 2 } & Estabelecer relações entre cidadania, sociedade e ambiente. \\
\hline AC cultural & Não houve evidências dessa categoria. \\
\hline
\end{tabular}

Fonte: Os autores (2019).

As subcategorias emergentes seguiram um padrão específico. A primeira subcategoria está relacionada ao desenvolvimento da alfabetização científica baseado em conhecimentos prévios dos estudantes, obtidos principalmente durante a problematização inicial. A segunda é referente aos conhecimentos adquiridos por meio da sequência didática desenvolvida durante as aulas, principalmente na etapa de organização do conhecimento e aplicação do conhecimento, quando ocorre a sistematização do conhecimento.

\section{Resultados e Discussões}

Para melhor analisar os resultados obtidos, o gráfico 1 apresenta o número das evidências referentes às categorias de Bybee (1995) e suas subcategorias. O Gráfico 2 refere-se às categorias de Shen (1975), salientando que suas evidências 
foram obtidas mediante a unitarização e classificação de excertos obtidos por meio da gravação dos diálogos obtidos durante as aulas, das atividades e dos relatórios realizados pelos alunos durante as aulas.

Gráfico 1: Quantidade de evidências referentes às categorias de Bybee e às subcategorias por nós elaboradas.

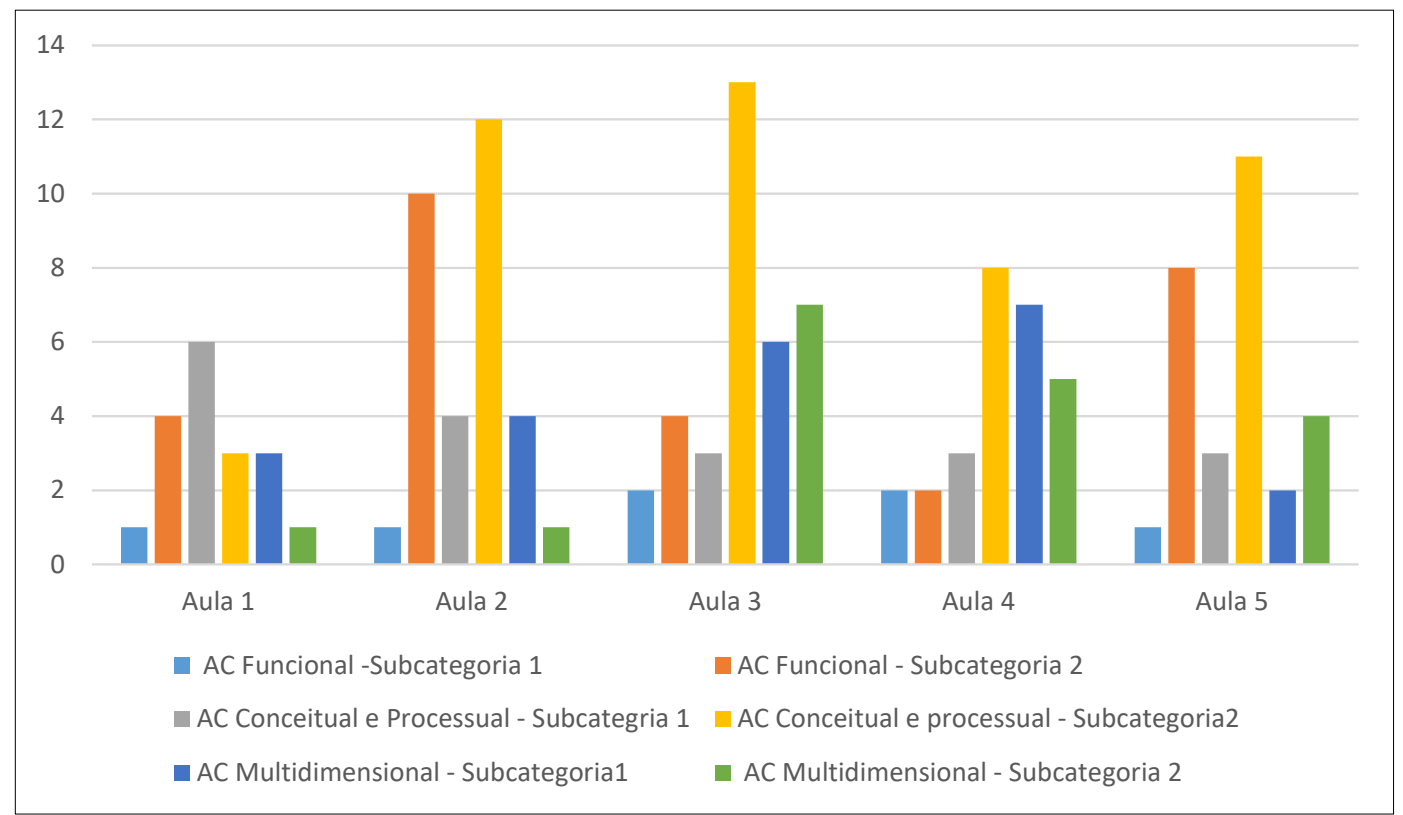

Fonte: Os autores (2019).

Com base no Gráfico 1 é possível verificar o predomínio da $\mathrm{AC}$ conceitual e processual, com 65 relatos no total, seguida pela AC multidimensional, com 40 e a AC funcional com 35. É importante reiterar que a categoria AC conceitual e processual é caracterizada pela compreensão e reprodução do significado de conteúdos e conceitos científicos. Consideramos que o número expressivo de ocorrências da AC conceitual e processual pode ser explicado pela forma como os professores e os sistemas de ensino conduzem e priorizam a aprendizagem, em sua grande maioria enfatizando o domínio de conceitos. Assim, os alunos acabam relatando os conceitos em suas falas e produções textuais, fato que está enraizado no desenvolvimento das aulas de Ciências.

Com base no Gráfico 1 é possível identificar também as similaridades da quantidade das evidências em cada aula, com exceção da primeira aula. Acreditamos 
que isso pode ter ocorrido devido ao fato de ser a aula inicial, onde os estudantes ainda estavam se adaptando à nova metodologia de ensino.

$\mathrm{Na}$ segunda aula houve crescimento significativo das evidências, demonstrando indícios de que os estudantes começaram a compreender o desenvolvimento da metodologia e que inclusive já se apropriaram de níveis de alfabetização científica que abarcam as categorias de Bybee. Além disso, é possível observar que nas categorias funcional, processual e conceitual, as subcategorias 2 foram mais evidenciadas, apresentando sinais de que os alunos assimilaram mais os conteúdos com o desenvolvimento da sequência didática do que em relação àqueles que já os detinham previamente.

Acreditamos que a proximidade do número de evidências totais em cada aula ocorreu devido ao fato de haver inter-relação entre as cinco aulas. Zabala (1998) ressalta a necessidade de, ao se planejar as aulas de uma unidade didática, ter em mente que o tema estruturante precisa estar articulado entre as aulas, para assim, ter-se uma sequência adequada, capaz de alcançar os objetivos almejados.

Apresentamos a seguir a análise das categorias e subcategorias com base nos pressupostos de Shen (1975).

Gráfico 2: Quantidade de evidências referentes às categorias de Shen e às subcategorias por nós elaboradas.

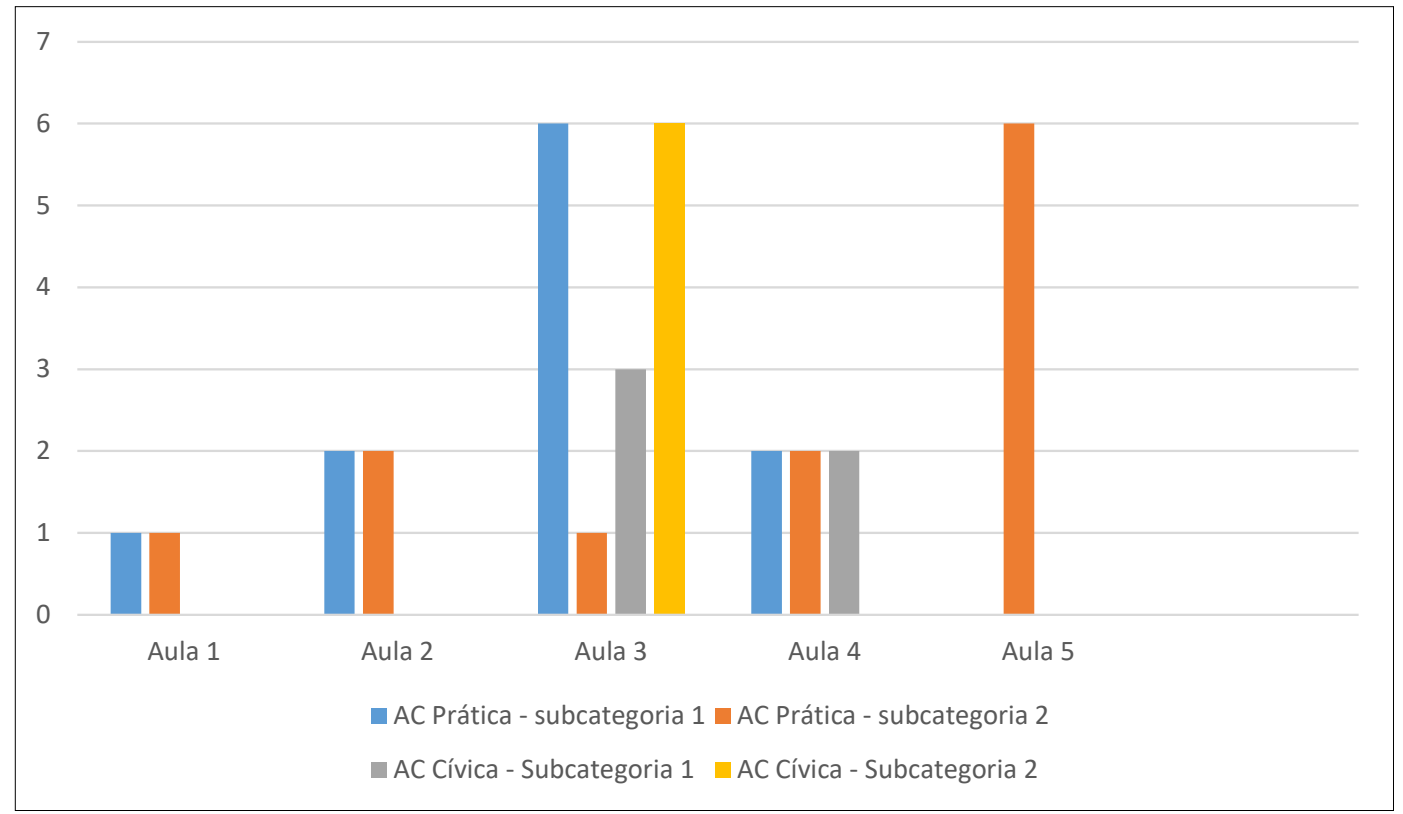

Fonte: Os autores (2019). 
Embora as categorias de Shen possuam sentidos próprios, o desenvolvimento de cada uma delas apresenta implicações diretas nas demais. Segundo Oliveira (2015) o ideal seria que as categorias fossem trabalhadas juntas, pois demonstram resultados mais significativos para formação dos estudantes.

O estudo constatou evidências das categorias de Shen, sendo que a AC prática apresentou 23 ocorrências, a AC cívica 11 e a AC cultural não foi evidenciada. Acreditamos que as evidências para a $\mathrm{AC}$ prática apresentou um grande número de ocorrência devido à similaridade com questões cotidianas que envolvem a temática, as quais foram discutidas em cada uma das aulas. Porém, na primeira aula houve menos evidências, se comparada às aulas 2 e 4, as quais podemos observar a similitude entre as subcategorias, divergindo das aulas 3 e 5, em que houve disparidade.

As evidências da categoria AC cívica emergiram nas aulas em que foram tratadas questões de cidadania e conscientização em relação a âmbitos sociais que envolvem a temática. Por isso que, se comparada a quantidade total de evidências, a aula 3 traz mais elementos para promover a alfabetização científica.

Como desafio, decidimos tratar da temática crustáceos sob diferentes vieses, para que fossem trabalhados elementos relacionadas à sociedade, economia, ciência e ambiente. Portanto, é importante salientar que a especificidade do tema determina até certo ponto a abrangência das categorias da AC, favorecendo uma ou outra. Desse modo, é esperado que algumas categorias sejam mais frequentes e outras menos. É natural também que conhecimentos científicos de aulas anteriores sejam repetidos nas seguintes, enfatizando que houve apropriação do conhecimento.

A ausência da AC cultural demonstra a dificuldade de identificá-la no contexto escolar, uma vez que seu enfoque é despertar o interesse do aluno em ampliar o seu conhecimento, para além dos conhecimentos sistematizados no contexto escolar. Durante a elaboração da sequência didática, buscamos desenvolver atividades que proporcionassem potencialidades para a AC cultural, muitas delas almejavam proporcionar aos estudantes o desejo de conhecer mais sobre o assunto, pesquisando e investigando assuntos que vão além do que está sendo estudado em sala de aula, mas não encontramos evidências nos episódios analisados.

$\mathrm{O}$ fato de não haver episódios representativos a AC cultural e poucos de AC cívica, pode ser um sinal de advertência para o ensino de Ciências. Isso pode representar uma consequência do início da vida escolar, época em que os alunos recebiam o conteúdo pronto e acabado pelo professor, levando-os a se habituarem a esse método 
passivo de ensino. Segundo Lorenzetti (2000) o ideal seria que o estudante sentisse a necessidade de ir além, pesquisando mais sobre o conteúdo para se aprofundar de maneira autônoma. Esse deveria ser o objetivo principal do ensino de ciências, contribuindo com a formação crítica e autônoma dos indivíduos.

Outro aspecto considerado a partir dessa lacuna da aprendizagem, é o fato de os estudantes refletirem a cultura da sociedade vigente, pouco democrática e participativa, a qual pensa na escola como uma bolha, desconectada do mundo. Nas instituições de ensino essa categoria é pouco enfatizada, principalmente para a formação de indivíduos com autonomia. Acreditamos que a escola representa a reprodução de um modelo dessa sociedade que vive uma profunda crise no modelo democrático do país, com pouca participação ativa. O objetivo da AC Cultural é ultrapassar o contexto escolar, despertando o interesse de conhecer mais sobre o conteúdo estudado, para que sintam a necessidade disso como iniciativa própria. Logo, era esperado a pequena expressão de evidências nessa categoria.

Nesse sentido, consideramos que o modelo da sociedade atual oprime os estudantes, restringindo o espaço de desenvolvimento da autonomia e de posicionamento. No âmbito escolar, essa tendência se expressa pela falta de espaço para o desenvolvimento autônomo, ainda priorizando-se a transmissão do conhecimento científico pronto e acabado.

Relacionando o número total de evidências, notamos que as evidências para categorias de Shen é expressivamente menor do que às do Bybee, demonstrando que o direcionamento dado a cada uma das aulas contribuiu para a ocorrência das evidências das categorias e subcategorias em geral.

Dentre os episódios identificados, foi selecionado o mais representativo, de maneira a demonstrar as análises e o que foi considerado em cada subcategoria, as quais serão apresentadas a seguir. Os alunos foram identificados como A1, A2 a A17 e a professora pesquisadora como $\mathrm{P}$.

\section{Alfabetização Científica Funcional}

Como citado anteriormente, esta categoria se caracteriza pela aquisição de conceitos, vocabulário, palavras técnicas relacionadas à ciência, podendo ser considerado uma fase inicial do desenvolvimento da AC. Os episódios que representam essa categoria são indícios de compreensão de termos relacionados ao conhecimento, 
identificados nas atividades dos estudantes, nas discussões e no relatório escrito ao final da aula.

\section{1• Subcategoria - Identificar e utilizar termos científicos assimilados anteriormente}

Na primeira aula os estudantes escutaram e acompanharam a letra da canção "O vendedor de Caranguejo" com o intuito de compreender a narrativa e os termos científicos. Após isso, foi questionado:

P: Quais os seres vivos que aparecem na música?

A13: Caranguejo e o cara que tá cantando a música e o filho.

A11: O cara e o filho são o mesmo ser vivo.

P: Qual é o nome dos seres vivos da música?

A4: Os nomes das espécies de caranguejos, Uçá e Guaiamum.

A14: Os nomes dos caranguejos, Uçá e Guaiamum.

Notamos que nesse episódio os estudantes apontam o caranguejo e o ser humano, quando questionados sobre quais seres vivos estão presentes na música. Um estudante, ao citar "o cara e o filho" apresenta indícios de que reconhece as espécies da canção e as relaciona ao fato de serem os mesmos seres vivos. Logo ao perguntar sobre o nome dos seres vivos, foram citadas as espécies de caranguejo.

Isso, de acordo com Bybee (1995), representa traços de AC funcional, demonstrando que apreenderam termos científicos relacionados ao tema, relacionando ao conceito de seres vivos, que foi estudado em aulas anteriores. Além disso, essa evidência também foi considerada como uma AC prática, pois para Shen (1975) essa categoria também abrange a aplicabilidade do conteúdo científico no contexto em que se vive, o que foi exposto na fala dos alunos.

Para que sejam alcançadas as categorias de alfabetização científica, o papel do docente é fundamental, uma vez que tudo expressado nesse episódio partiu de conhecimentos adquiridos anteriormente. O professor, ao ensinar o conhecimento científico, pode proporcionar autonomia para os estudantes envolvidos, bastando que ele tenha em mente os pressupostos da AC como meta, para que sejam capazes de recorrer ao conhecimento científico frente a problemas cotidianos (GARRITZ, 2012). O autor acrescenta que é essencial visar a "formação de indivíduos de ma- 
neira integral e ininterrupta em três grandes áreas: o conjunto de conhecimentos (o saber), habilidades (saber, pensar, saber fazer) e atitudes (saber estar e viver com os outros)" (GARRITZ, 2012, p. 129).

\section{$2^{\circ}$ Subcategoria - Utilizar novos termos científicos adquiridos}

No início da segunda aula, os alunos cantaram uma cantiga relacionada ao habitat natural do caranguejo - ecossistemas aquáticos. A canção "Caranguejo peixe é" foi trabalhada com a finalidade de discutir sobre o local onde habitam e o conceito que o termo científico "habitat" representa. Para trabalhar a cantiga, foi questionado sobre o habitat do caranguejo, que está localizado próximo ao do peixe, uma vez que ambos necessitam da água.

\section{P: Onde vive o caranguejo?}

A14: Na verdade, ele vive em dois lugares, na areia e na água.

A10: No mangue, que é seu habitat.

O fato de A10 ter utilizado o termo "mangue" e "habitat" como resposta é um indício de que se apropriou do conceito da palavra durante a aplicação da proposta didática, considerando que foram conceitos discutidos na primeira aula. Isso caracteriza uma AC Funcional, a qual utiliza termos científicos adequados em sua fala. Além disso, ao fazer a relação entre os termos destacados acima, o estudante demonstrou que compreendeu que o manguezal é o habitat do caranguejo, caracterizando também uma $\mathrm{AC}$ conceitual e processual, uma vez que articulou o conceito do termo científico ao seu significado. De acordo com Lorenzetti (2000), atividades que possibilitam a compreensão do conhecimento científico articulado a outros conhecimentos, ampliando a cultura do estudante, são significativas a alfabetização científica.

Isso deve estar presente no planejamento escolar, pois pode influenciar no desenvolvimento não só da aula, mas também do estudante. Portanto, avaliamos que o planejamento de uma sequência didática precisa ser aprimorado, pautando-se na elaboração de atividades que comportem o objetivo estipulado pelo professor para o desenvolvimento da proposta. 


\section{Alfabetização Científica Processual e Conceitual}

Esta categoria está ligada à capacidade de gerar significados aos conceitos e fenômenos científicos compreendidos anteriormente pela $\mathrm{AC}$ funcional, pois segundo Bybee (1995), ao se apropriarem dessa categoria, os indivíduos expressam que já houve ampliação de conhecimentos em relação à categoria a AC funcional. Esses significados podem ser atribuídos com sentidos próprios, trazendo informações e fatos que demonstrem compreensão e articulação à processos que fazem da ciência um modo de conhecer o mundo.

\section{1• Subcategoria _ Expressar o significado de conceitos científicos compreendidos previamente}

Na aula 5 houve uma discussão sobre a morfologia do caranguejo, principalmente sobre a maneira como as patas são dispostas no cefalotórax do animal. Ao longo da discussão, a professora pesquisadora interveio, explicitando o conceito de adaptação, que faz os seres vivos possuírem características próprias e específicas para seu tipo de vida. Os estudantes tecem seus comentários:

P: As patas arranjadas lateralmente fazem parte da adaptação dos caranguejos para o modo de vida que possuem nos mangues.

A5: Viu, A13? O bicho tem que ser com a forma certa para viver naquele habitat dele, senão não sobrevive. [...]

A12: Entendi porque a aranha é parecida com o caranguejo. Isso é os artrópodes, com exoesqueleto para todos.

Nesse episódio, o que representa a categoria é o relato do estudante ao final da discussão, quando expôs que compreendeu o significado de termo exoesqueleto, utilizando-o de maneira adequada e acrescentando que é uma característica específica dos artrópodes, conteúdo estudado anteriormente.

Além disso, anteriormente, um dos estudantes se apropria da fala da professora pesquisadora para falar sobre a necessidade de a morfologia do animal ser condizente com seu habitat, demonstrando que compreendeu o significado do termo adaptação. Esse trecho também representaria a segunda subcategoria da AC conceitual e processual, uma vez que os estudantes geraram significado aos termos estudados. Assim, podemos notar que ambas as falas que aparecem no episódio são 
indícios da $\mathrm{AC}$ conceitual e procedimental, mas em subcategorias distintas, visto que foram aprendidas ao longo do desenvolvimento da proposta didática, mas em aulas diferentes. É natural que isso aconteça, pois há uma conexão entre as duas subcategorias, resultantes dos parâmetros descritos por Bybee (1995).

Assim como citado na categoria de AC Funcional a categoria Conceitual e processual é importante para um dos pressupostos da $\mathrm{AC}$ - dar significado para o conhecimento científico. A segunda categoria avança um pouco nesse quesito, uma vez que amplia a visão restrita do significado, possibilitando articular diferentes conhecimentos científicos para um mesmo episódio.

\section{$2^{*}$ Subcategoria - Definir novos conceitos adquiridos}

Para essa categoria, foram consideradas evidências com manifestações de significados novos, apreendidos por meio da proposta didática. Na segunda aula, os indícios para essa subcategoria foram localizados em vários relatórios escritos ao final da aula:

A17: [...] mangue é um ecossistema que comporta vários animais terrestres ou/e marinhos.

A15: [...] O mangue é um ecossistema $[\ldots]$

A7: [...] tem lugares que as águas podem se misturar, entre doce e a salgada que pode se chamar salobra, que é a água dos oceanos, mares e rios que se misturam [...]

A4: [...] Vimos as garças, flamingo e guará que são os principais predadores do caranguejo.

Os trechos acima demonstram que houve compreensão de conhecimentos estudados e construção de conceitos, conforme os alunos reproduzem significados dos termos científicos: ecossistema, habitat, água salobra e outros.

É importante ressaltar que a única instrução passada para os alunos foi que confeccionassem os relatórios de acordo com a aula do dia. Com isso, os estudantes tiveram a liberdade de expor suas ideias. Nesta atividade, muitos alunos exibiram trechos do que estudaram na aula, incluindo conceitos científicos. Esses indícios caracterizam o relatório como um instrumento representativo de tal subcategoria.

O desenvolvimento dos relatórios é um dos recursos que podem contribuir para a construção de conhecimentos. Avaliamos como importante a utilização de diversos recursos didáticos para a promoção da alfabetização científica, principalmente por 
meio de sequências didáticas. Conforme Almeida (2012), os recursos que envolvem interpretação de fenômenos naturais auxiliam na promoção da alfabetização científica. É importante que haja variabilidade de recursos didáticos nas aulas de ciências, pois também pode motivar os estudantes e proporcionar subsídios para uma leitura de mundo.

Para Oliveira e Carvalho (2005, p. 348) a produção textual, realizada na construção do relatório, é um recurso importante para o ensino de ciências, pois de acordo com os autores "a escrita tem se destacado como um mecanismo cognitivo singular de organizar e refinar ideias sobre um tema específico". Assim, consideramos uma atividade de extrema relevância, para que sejam proporcionados momentos em que os estudantes possam exprimir suas reflexões sobre o assunto discutido na aula.

\section{Alfabetização Científica Multidimensional}

Esta categoria está relacionada à possibilidade de aquisição e explicação dos conhecimentos para aplicá-los na solução de problemas do cotidiano. Esse processo começa pela AC funcional, que ao ser apropriada passa para a categoria conceitual e processual, chegando até a AC multidimensional, momento em que conseguem aplicar o que aprenderam, estabelecendo relações diversas com o conteúdo, momentos mais aprofundados do desenvolvimento da AC.

\section{1`Subcategoria - Relacionar e aplicar os conteúdos estudados anteriormente}

O trecho destacado provém da apresentação dos estudantes sobre a história em quadrinhos lida e comentada na aula 4. De acordo com a concepção desta categoria, nessa aula acreditamos que podem haver muitas evidências, visto que os estudantes se sentiram confortáveis para expressar, de sua maneira, a suas ideias e conclusões sobre a problemática da história.

A10: Na minha história, utilizaram o lixo para fazer um espantalho, como reciclagem. Eu acho que a minha história pode ser a solução para outras histórias que tinham o lixo como problema. Porque todo o lixo ia para o rio, aí eles reaproveitaram a sucata, reciclagem.

Como demonstrado no Quadro 1, que sintetiza cada uma das cinco aulas estabelecidas na SD, em uma das etapas da aula 4, os alunos realizaram a leitura de histórias em quadrinhos da revista "Menino Caranguejo". Cada estudante recebeu 
uma revista diferente, com histórias distintas, embora relacionadas a problemáticas ambientais.

$\mathrm{Na}$ evidência destacada, o estudante em questão identificou que a temática ambiental era comum nas revistas de seus colegas e concluiu que o tema de sua história - reciclagem - poderia ser a solução para as demais. Esse aluno, abarcou conhecimentos adquiridos anteriormente que estavam presentes em sua revista em quadrinho, aprofundou e articulou-os às histórias anteriores, apresentando-as para os colegas com uma solução.

Tratar de temáticas ambientais vai ao encontro das orientações dos Parâmetros Curriculares Nacionais (PCN) de ciências. O documento em questão traz uma meta a ser trabalhada a partir de temas transversais, entre eles o meio ambiente, pois "trabalhar de forma transversal significa buscar a transformação dos conceitos, a explicitação de valores e a inclusão de procedimentos, sempre vinculados à realidade cotidiana da sociedade, de modo que obtenha cidadãos mais participantes" (BRASIL, 1998, p. 193).

Nesse sentido, a articulação de questões envolvendo a Ciência, a Tecnologia e a Sociedade, pode contribuir para o desenvolvimento da alfabetização científica, pois possibilitam a proximidade dos conteúdos com a vida dos estudantes, podendo, inclusive, efetivar relações com situações diversas. Além disso, essa articulação pode facilitar a leitura do mundo em que vivem e até mesmo transformá-lo, ao haver posicionamento crítico frente a situações problemáticas, com argumentos pautados e fundamentados a partir do conhecimento científico (CANIÇALLI, 2014).

Contudo, nesse episódio também podemos considerar indícios de AC Cívica, no momento em que o estudante reconhece o problema e gera uma solução relacionada aos aspectos ambientais, trecho em que aponta a reciclagem como uma solução para a poluição causada pelo descarte do lixo. De acordo com Shen (1975), a categoria de AC cívica abarca posicionamento e articulação do conhecimento com questões CTS.

\section{Subcategoria - Reconhecer e aplicar novos conteúdos assimilados}

A aula 5 foi realizada por meio de atividades no laboratório de ciências. Em grupos, os estudantes tinham em suas bancadas três exemplares de crustáceos taxidermizados. Cada grupo analisou três espécies por tempo determinado. Em seguida, houve a troca dos animais entre os grupos, e em meio aos comentários: 
A8: Se pensar no lugar onde vivem, dá para imaginar muitas coisas, tipo alimentação e reprodução.

A5: O caranguejo e o siri são diferentes. A carapaça do caranguejo é redonda a do siri não.

A6: Esse é um caranguejo fêmea que o abdômen tem o desenho redondo.

A1: O macho tem o desenho em triângulo.

A10: Craca parece ostra.

A1: Acho que essa quitina, que a professora falou que os crustáceos tem, é resistente mesmo, porque tem bicho que não tá com álcool e ainda tá conservado.

A12: Eu nunca vi um desses na praia. [...]

Sem que fosse pedido, muitos dos estudantes compararam os animais, tentando diferenciá-los, utilizando conhecimentos já adquiridos em momentos anteriores a esta aula para descrevê-los, dando sinal da primeira subcategoria da AC multidimensional. A exposição de reflexões, contribuiu para o desenvolvimento da oralidade do estudante, para a exteriorização das ideias e pensamentos, bem como para a compreensão da linguagem científica.

Nesse sentido, consideramos que o diálogo é importante para a promoção da alfabetização científica. Conforme Sasseron e Carvalho (2008) dependendo da organização dessas discussões, as interações discursivas podem proporcionar aprendizagem de temas relacionados à ciência. Diante disso, acreditamos que o professor tem um papel essencial nessa etapa, a partir da capacidade de mediar as discussões.

No decorrer das aulas, durante os momentos de discussão, foram esclarecidos aspectos pontuais discutidos pelos participantes, valorizando cada comentário, para que continuassem participando ativamente da aula e das atividades em geral.

Outro aspecto essencial para a promoção da alfabetização científica é ouvir os questionamentos e retornar com indagações, conduzindo ao entendimento mais do que entregá-lo pronto, para que o estudante problematize, se posicionando de maneira autônoma para compreender a situação. Para Delizoicov, Angotti e Pernambuco (2011), o sentido de escutar e compreender, contribui para essa valorização, considerando o aluno como alguém que tem visões diferentes sobre fenômenos e fatos científicos e que fazem parte do seu contexto social e natural. 
Contudo, o trecho que caracteriza de modo mais expressivo essa subcategoria é a fala que traz o elemento quitina, característica dos artrópodes. O uso demonstra que o aluno se apropriou do termo, da função da quitina no exoesqueleto desses animais, transcendendo o que foi discutido nos limites dessa aula, caracterizando uma AC multidimensional. Nesse episódio, também é possível identificar indícios de $\mathrm{AC}$ conceitual e processual nas falas que explicam a diferença morfológica entre caranguejo macho e fêmea, questão tratada em aulas anteriores da sequência didática.

As categorias de Bybee (1995) partem do ponto de vista do conhecimento, isto é, da cognição. Para apresentar indícios das categorias, o estudante precisa se apropriar do conteúdo - conceitos, termos científicos, etc. A cada nova discussão deve agregar novas palavras com significados e as aplicar como soluções para o dia a dia. Em outras palavras, as três categorias relacionam o ponto de vista do aluno à compreensão do conhecimento, representando, na ordem, adquirir, explicar e aplicar (AC funcional, AC conceitual e processual e AC multidimensional).

Já as categorias de Shen (1975) partem daquilo que se pretende, do que se pode fazer com o conhecimento aprendido, ou seja, do ponto de vista da intencionalidade. Para melhor expô-las, a seguir serão discutidas e analisadas as categorias desse autor, que representam a capacidade de relacionar aspectos que efetivamente 0 estudante compreendeu sobre o conteúdo.

No entanto, embora as categorias se Shen (1975) possuam sentidos próprios, o desenvolvimento de cada uma delas tem implicações diretas nas demais. Portanto, são integradas, e possuem o intuito de direcionar olhares acerca dos desdobramentos sociais da ciência. Convém ressaltar que, apesar das análises das categorias estarem separadas, o objetivo comum que as une é a formação de cidadãos capazes de compreender e atuar na sociedade atual.

\section{Alfabetização Científica Prática}

Para Shen (1975) a Alfabetização científica prática é o ponto de partida para outros níveis de alfabetização científica, pois se relaciona com as necessidades básicas do cotidiano e com a capacidade de os estudantes reconhecerem e utilizarem conhecimentos científicos, relacionando-os ao cotidiano. 


\section{1' Subcategoria - Relacionar os conhecimentos apreendidos anteriormente para resolução de problemas científicos}

$\mathrm{Na}$ segunda aula foi identificado um indício característico desta subcategoria. O episódio ocorreu no momento em que os estudantes foram convidados a refletir sobre a relação do conteúdo estudado com o local onde residem, como uma maneira de pôr em prática o conhecimento, contextualizando:

P: Tem mangue em Curitiba?

A3: Não, porque Curitiba não é perto do mar.

A16: Para ter manguezal, tem que ter estuário, água salgada e doce.

A3: A Rússia não tem manguezal.

A16: Óbvio que não, lá só tem frio.

\section{A8: Aqui perto só tem mangue em Paranaguá, Matinhos e Pontal.}

O trecho selecionado demonstrou que os estudantes conseguiram associar as condições necessárias para se constituir um manguezal com a realidade de cada região. Inclusive a definição apresentada por um dos estudantes é reflexo do conteúdo estudado, caracterizando uma AC conceitual e processual também.

Porém, a evidência mais representativa está relacionada ao dia a dia do estudante, conforme demonstra que houve apropriação do conhecimento novo relacionado aos conhecimentos anteriores. Isso ocorreu ao apresentar um conhecimento prévio, citando às cidades litorâneas paranaenses que possuem manguezais, indicando evidências desta subcategoria.

Para atingir o objetivo da sequência didática e contribuir para a promoção da alfabetização científica, acreditamos que não basta o estudante aprender apenas 0 significado dos conceitos, ele precisa ser capaz de utilizá-lo e aplicá-lo em diferentes situações. Para isso, Zabala (1998) ressalta a interpretação, a compreensão e a exposição, como aspectos fundamentais. Conforme o autor, esse ponto pode também tornar o estudante capaz de situar os fatos e objetos que envolvem o conceito científico.

Nesse aspecto, Lorenzetti (2000) ressalta que há necessidade de um encaminhamento metodológico para a prática pedagógica com foco na promoção da alfabetização científica. Na presente sequência didática, buscamos alcançar esse objetivo por meio 
da metodologia dos três momentos pedagógicos (3MP), pois de acordo com o autor supracitado, essa metodologia pode oportunizar a sistematização e ampliação do conhecimento se articulada à ação do professor.

\section{2* Subcategoria - Apreender novos conhecimentos estudados, como problemas} científicos

$\mathrm{Na}$ aula 4, após um estudante expor sua história em quadrinhos, que retrata uma situação em um lixão:

A5: O problema da história é porque se passa no lixão.

A6: A história é diferente porque o próprio caranguejo juntou o lixo em uma pilha, para deixar o mangue mais organizado e limpo. Isso é o que a gente viu naquela aula que falava que o caranguejo é um jardineiro.

A primeira fala representa a identificação de um problema na história em quadrinhos lida por outro estudante, não citado no trecho em destaque. Na sequência, o colega faz a relação do conhecimento que foi adquirido na aula 3 da proposta didática, sobre o caranguejo como jardineiro do manguezal, demonstrando que se apropriou do conhecimento e o utiliza para soluções de problemas científicos, característica desta subcategoria.

Vale ressaltar que esse assunto foi discutido na aula 3 após a leitura de um texto científico publicado na revista Ciência Hoje. Os PCN salientam a importância de o estudante ter acesso a textos informativos, uma vez que requerem domínio de diferentes habilidades e conceitos para a leitura, como objetivo do ensino de ciências (BRASIL, 1998). Além disso, Lorenzetti (2000) também ressalta a importância de leituras científicas, e as cita como um dos recursos que podem proporcionar o desenvolvimento da AC.

\section{Alfabetização Científica Cívica}

Esta categoria se caracteriza pelo desenvolvimento da capacidade tomar decisões e se posicionar a partir do conhecimento científico. Para Lorenzetti (2000), esse parâmetro serve como base para habilitação de cidadãos para lidar com assuntos relacionados à saúde, energia, recursos naturais, alimentação, ambiente, etc. $\mathrm{Ou}$ seja, se refere à condição de desenvolver um posicionamento crítico para a tomada de decisão em relação aos problemas científicos que afetam a sua vida. 


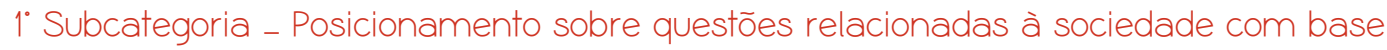
em conhecimentos prévios

Em diversos momentos os alunos apontaram a necessidade de mudança sobre fatos que relacionam o caranguejo e outros conhecimentos além da temática, geralmente questões sociais. Em outros momentos demonstraram comprometimento, ao citarem elementos que podem auxiliar a mudar a realidade de pessoas envolvidas com a pesca/caça do caranguejo.

Contudo, selecionamos um dos episódios que representou os pontos mais discutidos. Os argumentos se conduziram em torno da necessidade de tomada de atitude em relação aos problemas associados ao meio ambiente de maneira geral. Isso pôde ser identificado no momento em que os estudantes discutiam sobre a conscientização como maneira de amenizar a degradação do ambiente, pensando principalmente no ecossistema manguezal, habitat do caranguejo.

P: O que fariam como forma de conscientização para diminuir a poluição da região, ou para que não haja?

A1: Não jogar lixo.

\section{A8: Seja um cidadão consciente. Preserve essa região.}

A17: Colocar placas.

A5: Publicar na TV uma forma de cuidar dos caranguejos.

A1: Passar na rua falando: cuidem dos animais.

A16: Uma campanha... para acumular e chamar mais gente.

A4: [...] na internet.

A3: Ir em um lugar bem movimentado, na praia.

A9: Um restaurante, para as pessoas que estão próximos e vivem com o caranguejo.

A1: Fazer um clubinho... mostrar que eles estão em extinção e mostrar as causas $[\ldots]$

O episódio acima é bem representativo desta subcategoria, uma vez que os estudantes apresentaram elementos envolvendo a conscientização e a necessida- 
de de transformar a realidade, se posicionando ao citarem elementos capazes de proporcionar mudança. É possível observar, no trecho acima, que surgiram várias ideias para minimizar a extinção da espécie, caracterizando movimentos políticos.

Portanto, buscar a conscientização ambiental e o cuidado com a natureza foram elementos que sobressaíram nos fragmentos destacados, podendo representar traços para contribuição e transformação do quadro socioambiental da região.

Assim, podemos perceber que o conhecimento dos alunos em relação à temática avançou para além da aquisição de conteúdos e suas aplicações, mas para um posicionamento sobre a necessidade de se promover ações para o enfrentamento de problemas. Consideramos que essas ações podem envolver mudanças nas próprias atitudes e hábitos dos estudantes.

Desse modo, a consciência necessária para ações socioambientais pode indicar que o conhecimento passou a ser visto como um meio para tomada de decisões e não como um fim. Nesse sentido, essas constatações caracterizam os princípios da AC cívica, reforçando que o foco do ensino de ciências não é apenas contextualizar o conhecimento científico. É também "proporcionar condições para uma interpretação crítica da realidade e oportunizar meios para que os estudantes possam tomar consciência de seu papel no contexto social que estão imersos" (OLIVEIRA, 2015, p. 142).

\section{$2^{*}$ Subcategoria _ Estabelecer relações de cidadania com sociedade e ambiente}

No decorrer das diferentes aulas, foi possível observar visões antropocêntricas sobre os crustáceos e questões relacionadas, como quando a preservação do caranguejo foi notada apenas para o benefício humano, ignorando a importância para 0 ecossistema. A professora pesquisadora identificou o fato como sendo um problema não previsto, buscando alternativas para remediá-lo. A partir disso, a decisão foi trabalhar e discutir esse aspecto não programado com os próprios alunos que reproduziram essa visão.

O episódio selecionado representa uma das etapas dessa discussão. A mediação proporcionou elementos para a AC cívica, ao promover posicionamento crítico. No trecho abaixo os estudantes se apropriaram de conhecimentos adquiridos ao longo da proposta didática para elaborar seus argumentos: 
[...] A5: Se é fêmea ou macho e se não tiver com ovos.

A4: Dizer que ele tá vendendo caranguejo que não pode ser vendido. Isso é crime, vou ligar prá polícia agora [...]

P: Qual a vantagem de observar esses detalhes na hora de comprar?

A5: Você vai ajudar eles a nascerem e terem mais caranguejos.

A6: Mais caranguejos viverão e não têm extinção das espécies.

A8: Na próxima vez, vai ter bastante caranguejo de novo.

P: Qual a desvantagem de fazer essa observação?

A5: Nenhuma.

A8: Se todo mundo não comprasse esses caranguejos, com certeza a gente vai ter mais caranguejos por alguns anos.

Compreender o meio ambiente numa visão globalizante é refletir sobre toda espécie de ser vivo, inclusive os seres humanos, que fazem parte do meio ambiente. Nesse caso, é fundamental ter uma visão que contemple os aspectos CTS, demonstrando às pessoas que o caranguejo interfere em aspectos relacionados à sociedade e ao ambiente. Isso possibilita a compreensão de que, com o conhecimento adequado e estruturado, pode-se mudar a realidade atual e transformar o mundo, além de estimular o estudante a observar com criticidade os acontecimentos e tomar decisões quanto a isso.

De acordo com o episódio acima destacado, notamos a preocupação dos estudantes em contribuir para a preservação dos caranguejos, ao apontarem a relevância de conhecer o caranguejo para detectar detalhes que podem prejudicar a espécie no momento da compra do animal, posicionando-se perante tal situação. Isso é promover alfabetização científica.

\section{Considerações Finais}

Considerando o problema de pesquisa, podemos afirmar que os resultados foram significativos, pois foram observadas evidências de alfabetização científica para cada uma das categorias selecionadas, com exceção da categoria cultural. A análise dos 
dados constituídos durante e após o desenvolvimento da sequência didática apontou avanços rumo a uma proposta de ensino orientada para a alfabetização científica. O trabalho possibilitou o engajamento reflexivo dos estudantes nas discussões, e os discursos de muitos deles indicam metas da AC sendo alcançadas.

Com o desenvolvimento do presente estudo, percebemos o dialogicidade como um aspecto fundamental para melhorar o processo de ensino aprendizagem. Para Freire (1987) o conhecimento é construído na relação dos sujeitos, buscando pôr em diálogo questões humanas e sociais. Os pressupostos da AC estão associados a essa concepção de diálogo, valorizando-o em sala de aula como meio de romper com as práticas tradicionais, buscando formar cidadãos ativos na sociedade. Nesse sentido, as atividades por si só não são suficientes para promover e se fazer perceberem os pressupostos da AC. Argumentamos que a AC será desenvolvida por meio de uma prática reflexiva que permita desenvolver o raciocínio investigativo e o pensamento crítico, articulando as relações CTS ao ensino de ciências, à natureza do conhecimento científico e à apropriação de termos e conceitos científicos.

De acordo com o objetivo da pesquisa, que busca seguir as diretrizes da alfabetização científica, os elementos discutidos no estudo são essenciais para um ensino de ciências com qualidade, com o intuito de superar as aulas tradicionais expositivas, permitindo atingir novas perspectivas em relação ao papel do ensino de ciências. $\mathrm{O}$ domínio conceitual é importante no ensino de ciências, mas é crucial que os alunos transcendam a abstração, sendo capazes de aplicar o conhecimento em seu contexto sociocultural e ambiental. É imprescindível a apropriação do conhecimento para o posicionamento crítico frente a problemas científicos.

Nesse sentido, o estudo visou suprir uma fragilidade comum observada nas aulas de Ciências: a ausência de reflexões relacionadas a ambiente, sociedade e economia, ou seja, superar o ensino de ciências desvinculado da realidade concreta. Consideramos fundamental pensar o ensino de ciências de modo mais humano, capaz de proporcionar ao estudante a superação da simples apreensão passiva do conhecimento, incentivando-o a refletir, discutir e posicionar-se sobre os conteúdos estudados. Contempla-se, assim, a aplicação da temática e as inter-relações CTS para promover a $\mathrm{AC}$. 


\section{The promotion of scientific literacy in the last years of elementary education through a didactic sequence on crustaceans}

\section{Abstract}

This article aims to analyze the contributions of a didactic sequence implemented in the seventh grade of a public school in the state of Paraná, in 2015. The didactic sequence was based on parameters of scientific literacy and had as theme crustaceans. The study is characterized as a pedagogical intervention research. The constitution of the data occurred through the dialogues that were developed during the five consecutive classes of the disciplines of Science and Experimental Activities. As analysis methodology we used Discursive Textual Analysis. The planning of the didactic sequence was guided by the categories of scientific literacy denominated by Bybee (1995) as: functional, procedural and conceptual and multidimensional; taken together, the categories of Shen (1975) defined by practical, civic and cultural scientific literacy were adopted. These categories were used as a priori categories and, subsequently, the elaboration of subcategories proved to be important for the analysis. The results shown evidence of scientific literacy categories quite clearly, with the exception of cultural scientific literacy, which has not been identified. Some evidences of scientific literacy emerged from the students' previous knowledge and others, it could be observed, were promoted through the didactic sequence, which involved scientific, environmental, social and economic knowledge around the crustaceans theme. During the application of the didactic sequence, it was observed that, progressively, students developed a more critical position regarding the scientific, environmental, social and economic importance of crustaceans, acquiring scientific knowledge and skills in line with the assumptions of scientific literacy.

Keywords: Scientific Literacy; Didactic Sequence; Final grades of elementary school; Crustaceans.

\section{Nota}

1 Jogo de cartas que consiste em ganhar as cartas do adversário ao escolher características sobre o tema das cartas. Neste caso, as características dos caranguejos, como tamanho, largura, coloração, garras, etc. Ganha as cartas quem tiver as características mais adequadas para a sobrevivência, critérios selecionados previamente pelos próprios estudantes.

\section{Referências}

ALMEIDA, M. J. Mediação da pesquisa na interpretação da educação em ciências. In: CARVALHO, A. M. (Org.), O ensino das ciências como compromisso científico e social. São Paulo: Editora Cortez, 2012, p. 137-159.

ARAÚJO, C. P. Ensino de ciências no ensino fundamental em diferentes espaços educativos usando o tema da conservação da fauna amazônica. 2014. Dissertação (Mestrado em Educação em Ciências na Amazônia) - Universidade do Estado do Amazonas, Manaus, 2014. 
AULER, D.; DELIZOICOV, D. Alfabetização científico-tecnológica para quê?. Ensaio - Pesquisa em Educação em Ciências, Belo Horizonte, v. 3, n. 1, p. 105-116, 2001.

BRASIL. Parâmetros curriculares nacionais: Ciências Naturais. Brasília: Secretaria da Educação Básica - MEC, 1988.

BYBEE, R. W. (1995). Achieving Scientific Literacy. The Science Teacher, Arlington, v. 62, n. 7, p. 28-33, 1995.

CACHAPUZ, A. F., GIL-PEREZ, D., CARVALHO, A. M. P., Praia, J.; VILCHES, A. A necessária renovação do ensino de ciências. São Paulo: Cortez, 2005.

CANIÇALLI, M. A. F. Clube de Ciências Escolar: Características, Formação e Sugestões de Atividades. 2014. Dissertação (Mestrado em Educação em Ciências e Matemática) - Instituto Federal do Espírito Santo, Vitória, 2014.

CHASSOT, A. Alfabetização científica: uma possibilidade para a inclusão social. Rio de Janeiro: Revista Brasileira de Educação, Rio de Janeiro, n. 22, p. 89-100, 2003.

COSTA, E. M., LORENZETTI, L. Parâmetros de Alfabetização Científica nos livros didáticos de ciências: analisando a temática artrópodes. In: ENCONTRO NACIONAL DE PESQUISA EM EDUCAÇÃO EM CIÊNCIAS, 11, Anais [...] Florianópolis, SC: ABRAPEC, 2017

COSTA, E. M., LORENZETTI, L. Disseminação da alfabetização científica nos anos finais do Ensino Fundamental: da produção acadêmica aos livros didáticos. REnBio - Revista de Ensino de Biologia da SBEnBio, Rio de Janeiro, v. 11, n. 1, p. 88-104, 2018.

DAMIANI, M. F. et al. Discutindo pesquisas do tipo intervenção pedagógica. Cadernos de Educação, Pelotas, p. 57-67, mai/ago. 2013.

DELIZOICOV, D.; ANGOTTI, J. A.; PERNAMBUCO, M. M. Ensino de Ciências: fundamentos e métodos. 4 ed. São Paulo: Cortez, 2011.

DOMICINO, T. D.; LORENZETTI, L., REIS, R. A.; JOUCOSKi, E. Potencialidades da feira regional de ciências do litoral paranaense para a alfabetização científica. In: ENCONTRO NACIONAL DE PESQUISA EM EDUCAÇÃO EM CIÊNCIAS, 11, Anais [...] Florianópolis, SC: ABRAPEC, 2017.

DRIVER, R.; ASOKO, H.; LEACH, J.; MORTIMER, E.; SCOTT, P. Construindo conhecimento científico na sala de aula. Química Nova na Escola, São Paulo, v. 9, p. 31-40, 1999.

FREIRE, P. Pedagogia do Oprimido. 17. ed. Rio de Janeiro: Paz e Terra, 1987

GARRITZ, A. Do químico teórico ao professor humanista: uma vida afortunada. In: CARVALHO, A. M. (Org.), O ensino das ciências como compromisso científico e social. São Paulo: Editora Cortez, 2012, p. 113-136.

HURD, P. D. Scientific literacy: new mind for a changing world. In: Science \& Education. Stanford, USA, n. 82, p. 407-416, 1998.

IGLESIA, P. M. Ciencia - tecnología - sociedad en la enseñanza-aprendizaje de las ciencias experimentales. In: Alambique: Didáctica de las Ciencias Experimentales. Barcelona, año II, n. 3, p. 7-11, ene. 1995.

LAUGKSCH, R. C. Scientific Literacy: A Conceptual Overview. Hoboken: Science Education, 2000 . 
LORENZETTI, L. Alfabetização Científica no contexto das séries iniciais. 2000. Dissertação (Mestrado em Educação) - Universidade Federal de Santa Catarina, Florianópolis, 2000.

LORENZETTI, L.; SIEMSEN, G.; OLIVEIRA, S. Parâmetros de alfabetização científica e alfabetização tecnológica na educação em química: analisando a temática ácidos e bases. ACTIO: Docência em Ciências, Curitiba, v. 2, n. 1, p. 4-22, 2017.

MILARÉ, T.; RICHETTI, G. P.; PINHO ALVES, J. P. (2009). Alfabetização científica no ensino de Química: uma análise dos temas da seção Química e Sociedade da Revista Química Nova na Escola. Química Nova na Escola, São Paulo, v. 31, n. 3, p. 165-171, 2009.

MILLER, J. D. Scientific literacy: a conceptual and empirical review. Cambridge: Daedalus, 1983.

MORAES, R.; GALIAZZI, M. C. Análise textual discursiva. Ijuí: UNIJUÍ, 2007.

OLIVEIRA, C. M. A.; CARVALHO, A. M. P. Escrevendo em aulas de ciências. Ciência \& Educação, Bauru, v. 11, n. 3, p. 347-366, 2005.

OLIVEIRA, S. Limites e potencialidades do enfoque CTS no ensino de química utilizando a temática qualidade do ar interior. 2015. Dissertação (Mestrado em Educação em Ciências e Matemática) - Universidade Federal do Paraná, Curitiba, 2015.

PIZARRO, M. V.; LOPES JUNIOR, J. Indicadores de alfabetização científica: uma revisão bibliográfica sobre as diferentes habilidades que podem ser promovidas no ensino de ciências nos anos iniciais. Investigações em Ciências, Porto Alegre, v. 20, n. 1, p. 208-238, 2015.

PFLANZER, R. Contribuições da temática vida saudável para o processo de alfabetização científica e tecnológica. 2017. Dissertação (Mestrado em Educação em Ciências e Matemática) - Universidade Federal do Paraná, Curitiba, 2017.

ROSA, T. F.; LAMBACH, M.; LORENZETTI, L. (2017). Nível de Alfabetização Científica e tecnológica dos itens de química no ENEM 2016. In: ENCONTRO NACIONAL DE PESQUISA EM EDUCAÇÃO EM CIÊNCIAS, 11, Anais [...] ABRAPEC: Florianópolis, 2017.

ROSA, T. F. O processo de construção de um game para o reconhecimento dos níveis de alfabetização científica e tecnológica no ensino de química. 2018. Dissertação (Mestrado Profissional em Formação Científica, Educacional e Tecnológica) - Universidade Federal Tecnológica do Paraná, Curitiba, 2018.

SASSERON, L. H.; CARVALHO, A. M. P. Almejando a Alfabetização Científica no Ensino Fundamental: a proposição e a procura de indicadores do processo. Investigações em Ensino de Ciências, Porto Alegre, v.13, p. 333-352, 2008.

SIEMSEM, G. H. O ensino de astronomia em uma abordagem interdisciplinar no ensino médio: potencialidades para a promoção da alfabetização científica e tecnológica. 2019. Dissertação (Mestrado em Educação em Ciências e em Matemática) - Universidade Federal do Paraná, Curitiba, 2019.

SHEN, B. S. P. Science literacy. American Scientist, v. 63, p. 265-268, 1975.

STANZANI, E. L.; BROIETTI, F. C. D.; SOUZA, M. C. C. Oficinas temáticas no ensino de química: (re)construindo significados a partir das finalidades da alfabetização científica. Experiências em Ensino de Ciências, Porto Alegre, v. 11, n. 2, p. 164-175, 2016. 
STRIEDER, R. B. Abordagem CTS e ensino médio: espaços de articulação. 2008. Dissertação (Mestrado em Ensino de Ciências) - Universidade de São Paulo, São Paulo. 2008.

STRIEDER, R. B. Abordagem CTS na Educação Científica no Brasil: sentidos e Perspectivas. 2012. Tese de Doutorado em Ciências) - Universidade de São Paulo, São Paulo, 2012.

STUART, R. C.; MARCONDES, M. E. As contribuições do processo de reflexão orientada na formação inicial de uma professora de Química: desenvolvimento de práticas investigativas e para a promoção da alfabetização científica. Revista Electrónica de Enseñanza de las Ciencias, Barcelona, España, v. 16, n. 1, p. 69-93, 2017.

TEIXEIRA, F. M. Alfabetização científica: questões para reflexão. Ciência \& Educação, Bauru, v. 19 , n. 4 , p. $795-809,2013$.

YAGER, R. Science, technology, society: a major trend in science education. In: UNESCO. New trends in integrated science teaching. Bélgica: UNESCO, p. 44-48, 1990.

ZABALA, A. Como trabalhar os conteúdos procedimentais em aula. Porto Alegre: Artes Médicas Sul, 1998. 